\title{
Pengaruh Variasi Dopan Asam Terhadap Kinerja Baterai Sekunder Polianilina|Zn
}

\author{
The Effect of Acid Dopant Variation on the Performance of Polyaniline|Zn Secondary Batteries
}

\author{
Said Ali Akbar ${ }^{1 *}$, Veinardi Suendo ${ }^{2)}$, Achmad Rochliadi ${ }^{2)}$ \\ ${ }^{1)}$ Universitas Serambi Mekkah, Pendidikan Kimia, Indonesia \\ ${ }^{2)}$ Institut Teknologi Bandung, Kimia, Indonesia \\ *email: said.aliakbar@serambimekkah.ac.id
}

Received: 07/06/20; Revised: 18/06/20; Accepted: 18/06/20

\begin{abstract}
Abstrak
Studi tentang baterai sekunder polianilina(PAni)|Zn telah banyak dikembangkan, tetapi sejauh ini masih belum ada penjelasan mengenai pengaruh asam terhadap kinerja baterai tersebut. PAni disitensis menggunakan metoda elektrodeposisi dengan tegangan 0,7 V selama 30 menit. PAni hasil sintesis dikarakterisasi menggunakan Voltammetri dan Spektroskopi Inframerah. Baterai PAni|Zn didesain dalam bentuk sandwich, kemudian pengukuran kinerja digunakan impedansi serta pengisianpengosongan. Baterai dengan elektroda $\mathrm{PAni}-\mathrm{Cl}$ dan $\mathrm{PAni}-\mathrm{Br}$ mempunyai kinerja yang lebih baik dengan specific capacity saat ke-60 yaitu 55,4 dan 37,4 $\mathrm{mAh} \mathrm{g}^{-1}$. Pengukuran impedansi pada baterai dengan elektroda PAni-Cl, PAni-Br, dan PAni $\mathrm{HClO}_{4}$, menunjukan resistance solution $\left(\mathrm{R}_{\mathrm{s}}\right)$ secara berurutan yaitu 1,$38 ; 2,56$; dan $3,03 \Omega$ dan resistance charge transfer $\left(\mathrm{R}_{\mathrm{ct}}\right) 2,24 ; 2,97$; dan 7,71 $\Omega$. Oleh sebab itu, baterai PAni|Zn dengan dopan $\mathrm{HCl}$ menunjukkan kinerja terbaik dibanding dengan asam yang lain.
\end{abstract}

Kata Kunci: baterai sekunder, dopan asam, Polianilina, specific capacity, Zn

\begin{abstract}
Studies on secondary polyaniline (PAni)|Zn batteries have been extensively developed, but so far there has been no explanation regarding the effect of acid on the performance of these batteries. PAni was synthesized using the electrodeposition method with a voltage of $0.7 \mathrm{~V}$ for 30 minutes. The synthesis results were characterized using Voltammetry and Infrared Spectroscopy (IR). PAni|Zn batteries are designed in the form of sandwiches, then the performance measurements are conducted by impedance and charge-discharge. The batteries with PAni-Cl and PAni-Br electrodes have better performance with specific capacity at 60, namely 55.4 and $37.4 \mathrm{mAh}$ g-1. Impedance measurements on batteries with PAni-Cl, PAni-Br, and PAni HClO4 electrodes, showed resistance solutions (Rs) in sequence, namely 1.38; 2.56; and $3.03 \Omega$ and resistance charge transfer $(R c t) 2.24 ; 2.97 ;$ and $7.71 \Omega$. Therefore, PAni|Zn batteries with $\mathrm{HCl}$ dopant show the best performance compared to other acids.
\end{abstract}

Keywords: acid dopant, Polyaniline, secondary batteries, specific capacity, $\mathrm{Zn}$ 


\section{PENDAHULUAN}

Aplikasi polimer konduktif seperti Polianilina (PAni) telah banyak dikembangkan pada perangkat elektronik seperti sensor, kapasitor, baterai, organic light emiting diodes (OLED), dan organic photovoltaic cells (OPVC) (Šeděnková $d k k$., 2016). Hal ini disebabkan karena PAni memiliki beberapa keunggulan seperti mudah difabrikasi, memiliki multilevel oksidasi, stabilitas yang baik, konduktivitas yang bervariasi, dan harga monomer yang murah dibandingkan dengan polimer konduktif yang lain (Chang dkk., 2018; Chen \& Manzhos, 2016; Deyab \& Mele, 2019).

PAni dapat disintesis dalam beberapa bentuk isolatifnya yaitu Leucomeraldine Base (LB) yang tereduksi penuh, Emeraldine Base (EB) yang teroksidasi setengah dan Pernigranilin Base (PB) yang teroksidasi enuh (Gao $d k k ., 2017$; Huang $d k k ., 2020)$. Bentuk EB dapat dibuat konduktif dengan proses pendopingan dengan asam (HX), dengan protonasi pada daerah $-\mathrm{N}=$, sementara jumlah elektron pada rantai tetap. Bentuk konduktif dari EB disebut Emeraldine Salt (ES) dengan konduktivitas 0,1-100 S/cm (Kawashima $d k k ., 2018$; Kurada \& De, 2018; Li $d k k$., 2019). Semakin kuat suatu dopan asam, maka konduktivitas PAni akan semakin baik. Penggunaan dopan asam seperti $\mathrm{HCl}, \mathrm{HBr}$, Camphorsulfonic acid, $\mathrm{HClO}_{4}, \quad$ dan $\mathrm{H}_{2} \mathrm{SO}_{4}$ untuk menurunkan resistansi dari material PAni telah dilaporkan (Hatchett $d k k .$, 1999; Zhao $d k k$., 2018 )

PAni banyak digunakan sebagai elektroda katalitik maupun komposit pada suatu material elektroda. Namun, PAni juga dapat dijadikan sebagai elektroda utama. Hal ini karena PAni memiliki sifat multilevel oksidasi dan redoks reversible (Luo dkk., 2016). Baterai PAni|Zn merupakan jenis baterai rechargeable berbasis PAni sebagai katoda. Baterai ini memiliki kinerja yang mirip dengan baterai Ni-MH, sehingga menjadi inovasi terbaru sebagai sumber penyimpan energi yang dapat bersaing dengan baterai $\mathrm{Ni}$ MH. Namun, baterai PAni|Zn mengalami kehilangan kapasitas pada saat beberapa kali proses pengisian-pengosongan (irreversible redox) (Taheri dkk., 2018; Zhao $d k k$., 2018 ). Hal tersebut membuat menurunnya kinerja baterai.

Pemanfaatan asam klorida sebagai dopan asam pada baterai PAni|karbon telah dilakukan dan ditemukan kerapatan

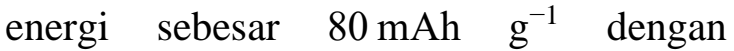
efisiensi coulomb 99\% (Zhao $d k k$., 2018 ${ }^{\mathrm{b}}$ ). Sintesis PAni dengan dopan $\mathrm{H}_{2} \mathrm{SO}_{4}$ menunjukkan endapan putih pada saat awal sintesis dengan terbentuknya jembatan sulfat antara 2 layer Pani. Hal ini bersifat meningkatkan konduktivitas, tetapi mengganggu stabilitas redoks (Hatchett dkk., 1999). Hanya sedikit laporan tentang penggunaan dospan asam lain pada elektroda PAni untuk aplikasi baterai. Oleh karena itu, pada studi ini dilakukan kajian tentang kinerja baterai PAni|Zn pada beberapa dopan asam yaitu $\mathrm{HCl}, \mathrm{HBr}$, dan $\mathrm{HClO}_{4}$.

\section{METODE PENELITIAN}

\section{Alat dan Bahan}

Peralatan analisis yang digunaka berupa Fourier-Transform Infra Red (FTIR). Bahan yang digunakan adalah anilina (Sigma-Aldrich), $\mathrm{ZnCl}_{2}$ (Merck), $\mathrm{ZnBr}_{2}$ (Merck), $\mathrm{Zn}\left(\mathrm{ClO}_{4}\right)_{2}$ (Merck), serbuk seng (Merck), $\mathrm{HBr} 47 \%$ (Merck), $\mathrm{HCl}$ $37 \% \quad$ (Merck), $\mathrm{KBr}$ (Merck), dimetilasetamida (DMAC) (Merck), 
$\mathrm{HClO}_{4} 60 \%$ (Merck), triton $\mathrm{X}-100$, aqua demineralisasi, dan aseton teknis.

\section{Sintesis Polianilina}

PAni disintesis menggunakan metoda elektrodeposisi. Sebanyak 3,72 g anilina $\left.\left(\mathrm{C}_{6} \mathrm{H}_{5} \mathrm{NH}_{2}\right), \quad \mathrm{M}_{\mathrm{r}}=93 \mathrm{~g} / \mathrm{mol}\right)$ dilarutkan ke dalam $100 \mathrm{~mL}$ masingmasing larutan asam pendopan $1 \mathrm{M}$. Dalam hal ini, asam pendopan yang digunakan adalah $\mathrm{HCl}, \mathrm{HBr}$, dan $\mathrm{HClO}_{4}$. Selanjutnya, larutan tersebut dimasukan kedalam sel dengan 3 elektroda yaitu, logam Pt sebagai elektroda lawan, Graphite Sheet (GC) sebagai elektroda kerja, dan $\mathrm{Ag} / \mathrm{AgCl}$ didalam larutan $\mathrm{KCl}$ jenuh sebagai elektroda pembanding. Proses polimerisasi ini dilakukan pada tegangan konstan sebesar $0,7 \mathrm{~V}$ selama 30 menit. Produk yang dihasilkan dicuci dengan aquades, lalu dicuci dengan asam pendopannya sendiri.

\section{Karakterisasi Polianilina}

Cyclic Voltammetry (CV)

Produk hasil sintesis disusun sebagai elektroda dalam wadah yang berisi larutan asam pendopannya. Pada sel ini terdiri dari 3 elektroda yaitu logam Pt sebagai elektroda lawan, PAni sebagai elektroda kerja, dan $\mathrm{Ag} / \mathrm{AgCl}$ didalam larutan $\mathrm{KCl}$ jenuh sebagai elektroda pembanding. Scanning dilakukan pada rentang voltase 0,2 V sampai $0,8 \mathrm{~V}$ selama 15 siklus. Kecepatan scanning yang digunakan adalah $50 \mathrm{mV} / \mathrm{s}$.

\section{Fourier-Transform Infra Red (FTIR)}

Sejumlah 0,2 mg PAni dicampurkan dengan $0,1 \mathrm{~g} \mathrm{KBr}$ di dalam mortar agate, dihaluskan sehingga keduanya bercampur merata. Selanjutnya, campuran PAni/KBr ditekan hingga terbentuk pelet PAni didalam matriks $\mathrm{KBr}$. PAni kemudian dianalisis menggunakan FTIR Bruker Alpha, dengan rentang bilangan gelombang $4000-550 \mathrm{~cm}^{-1}$ dan jumlah pemindaian sebanyak 16 kali. Prosedur yang sama dilakukan untuk ketiga jenis PAni.

\section{Pengujian Kinerja Baterai}

\section{a. Pengisian-Pengosongan}

Masing-masing baterai PAni dengan berbagai asam pendopan dianalisis performanya melalui proses pengisian dan pengosongan dengan Gamry Reference 3000. Proses ini menggunakan arus sebesar $10 \mathrm{~mA}$ selama 60 siklus. Cut off pada proses pengisian adalah $1,6 \mathrm{~V}$, sedangkan pada proses pengosongan adalah $0,7 \mathrm{~V}$. Prekondisi dilakukan pada awal siklus dengan cut off pengisian 1,65 $\mathrm{V}$, dan pengosongan $0,1 \mathrm{~V}$. Prekondisi ini bertujuan untuk memaksimalkan reaksi yang terjadi pada elektroda PAni.

\section{b. Electrochemical Spectroscopy (EIS)}

Masing-masing baterai PAni dengan berbagai asam pendopan diukur impedansinya pada suhu $27{ }^{\circ} \mathrm{C}$. pengukuran impedansi dilakukan dengan Gamry Reference 3000 menggunakan arus sebesar $1 \mathrm{~mA}$ dengan frequency sweep dari 0,1 $\mathrm{Hz}$ hingga $100 \mathrm{mHz}$. Data hasil pengukuran diekstrapolasi dalam bentuk kurva Nyquist.

\section{HASIL DAN PEMBAHASAN}

Polimerisasi anilina terjadi melalui reaksi oksidasi. Mula-mula anilina dilarutkan kedalam masing-masing asam pendopannya $\left(\mathrm{HCl}, \mathrm{HBr}\right.$, dan $\left.\mathrm{HClO}_{4}\right)$, sehingga diperoleh anilina yang terprotonasi. Selain bertujuan melarutkan 
anilina yang bersifat viskos, protonasi anilina juga membentuk kation anilinium yang cukup mudah teroksidasi (Sovizi \& Fahimi, 2018).<smiles>CC(C)(C)c1cccc(Nc2ccc([N+](=O)[O-])cc2)c1</smiles>

Gambar 1. Reaksi oksidasi dari kation anilinium.

Proses polimerisasi ini dilakukan pada tegangan konstan sebesar $0,7 \mathrm{~V}$ karena nilai voltase tersebut merupakan potensial oksidasi dari kation anilinium (Zhang $d k k .$, 2018). Sebelumnya, proses oksidasi diawali dengan mobilisasi ion anilinium menuju anoda. Pertama, kation anilinium mengalami solvasi membentuk awan ion yang bermuatan parsial negatif karena adanya pengaruh dipol-dipol. Selanjutnya, kation anilinium tersebut terimobilisasi menuju anoda melalui Outer Helmholtz Plane (OHP) dan Inner Helmholtz Plane (IHP) (Li dkk., 2019). Kation anilinium yang tersolvasi akan mengalami desolvasi pada OHP. Setelah itu, pada IHP ion anilinium yang sudah terdesolvasi akan cukup aktif untuk menuju anoda melalui cincin benzena yang bermuatan parsial negatif (Kurada \& De, 2018). Proses mobilisasi diilustrasikan pada Gambar 2

Setelah itu, kation anilinium teroksidasi di anoda (elektroda kerja) membentuk anilinium radikal positif. Selanjutnya, anilinium radikal positif akan mengalami dehidrogenasi membentuk anilina radikal positif. Pada bentuk ini, anilina radikal positif merupakan spesi aktif yang akan mengalami reaksi kopling membentuk rantai polianilina (Kawashima $d k k ., 2018)$.

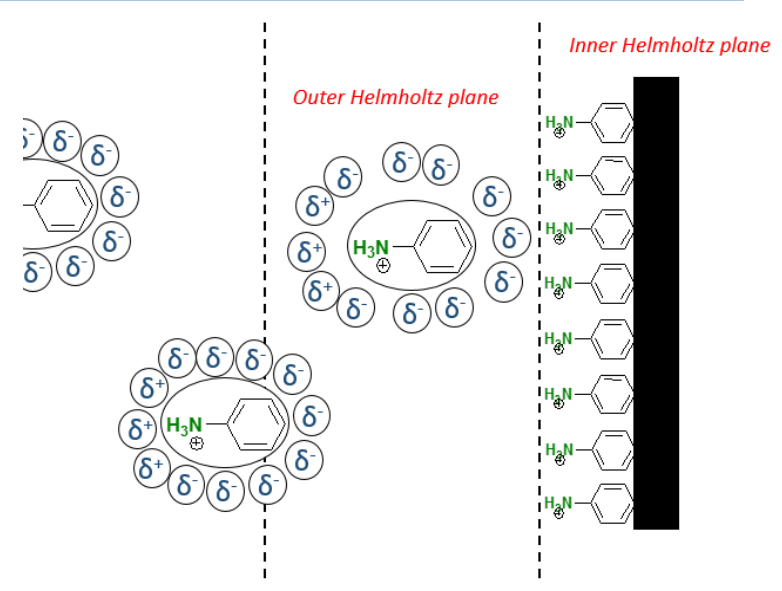

Gambar 2. Ilustrasi mobilisasi ion anilinium menuju anoda.

Proses polimerisasi dilakukan \pm 30 menit, hingga didapatkan massa produk sebesar $\pm 60 \mathrm{mg}$. Hasil sintesis dapat dilihat pada Gambar 3. PAni yang dihasilkan kemudian dicuci menggunakan asam klorida, untuk protonasi yang lebih optimal agar dihasilkan PAni-ES dengan konduktivitas tinggi. PAni selanjutnya dicuci dengan aseton untuk melarutkan oligomer yang terbentuk selama proses polimerisasi (Zhao $d k k$., 2018 ${ }^{\mathrm{b}}$ ).

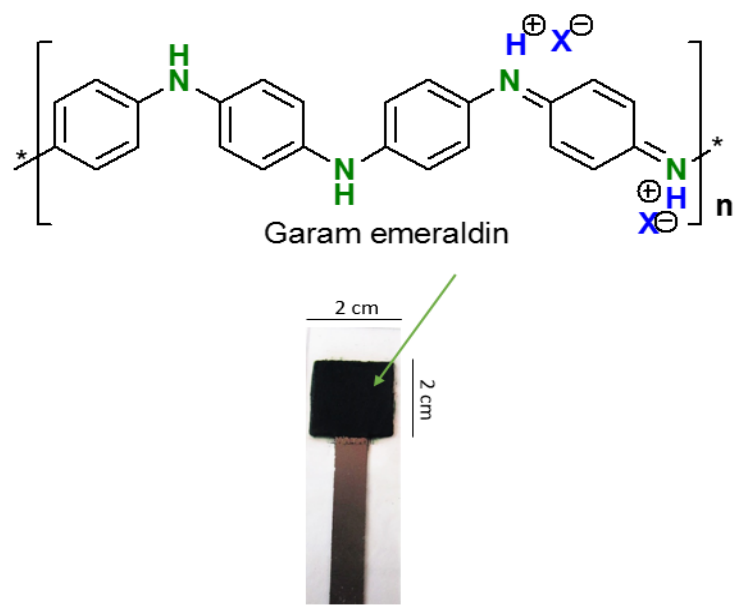

Gambar 3. Produk polianilina hasil sintesis.

\section{Karakterisasi Polianilina}

Cyclic Voltammetry (CV)

Profil proses elektrodeposisi anilina menjadi PAni dipelajari dengan menggunakan cyclic voltammetry (CV) 
Pengaruh Variasi Dopan Asam Terhadap Kinerja Baterai Sekunder Polianilina|Zn

yang dapat dilihat pada Gambar 4. Pada puncak anodik $\left(\mathrm{P}_{\mathrm{a}}\right)$ 0,22 $\mathrm{V}$ dan puncak katodik $\left(\mathrm{P}_{\mathrm{k}}\right)-0,08 \mathrm{~V}$ merupakan proses redoks yang terjadi antara leukoemeraldin dan emeraldin. Pada $\mathrm{P}_{\mathrm{a}}$ 0,74 V dan $\mathrm{P}_{\mathrm{k}} 0,58$ $\mathrm{V}$ seharusnya identik dengan redoks yang terjadi antara emeraldin dengan pernigranilin (Gao dkk., 2017). Namun puncak tersebut tidak terbentuk, karena dimungkinkan terjadinya kompetitif redoks dengan oksidasi dari air. Pada siklus awal proses Voltammetri, terlihat ada puncak kecil yang muncul pada $\mathrm{P}_{\mathrm{a}}$ $0,61 \mathrm{~V}$ dan $\mathrm{P}_{\mathrm{k}} \quad 0,51 \quad \mathrm{~V}$. Hal ini dikonfirmasi sebagai redoks dari pembentukan phenazine (Zhang $d k k$.,
2018). Puncak tersebut hilang seiring bertambahnya siklus.

\section{Fourier-Transform Infra Red (FTIR)}

Selanjutnya, PAni yang terbentuk dikaraterisasi menggunakan spektrum FTIR. Ketiga polianilina hasil sintesis menunjukkan daerah mode vibrasi penting yang mirip yang hasilnya dapat dilihat pada Gambar 5 dan Tabel 1. Serapan pada daerah $1560 \mathrm{~cm}^{-1}$ dan $1480 \mathrm{~cm}^{-1}$ mengindikasikan mode vibrasi dari ulur $\mathrm{C}=\mathrm{C}$ pada cincin kuinoid dan ulur $\mathrm{C}=\mathrm{C}$ pada cincin benzenoid (Deyab \& Mele, 2019).
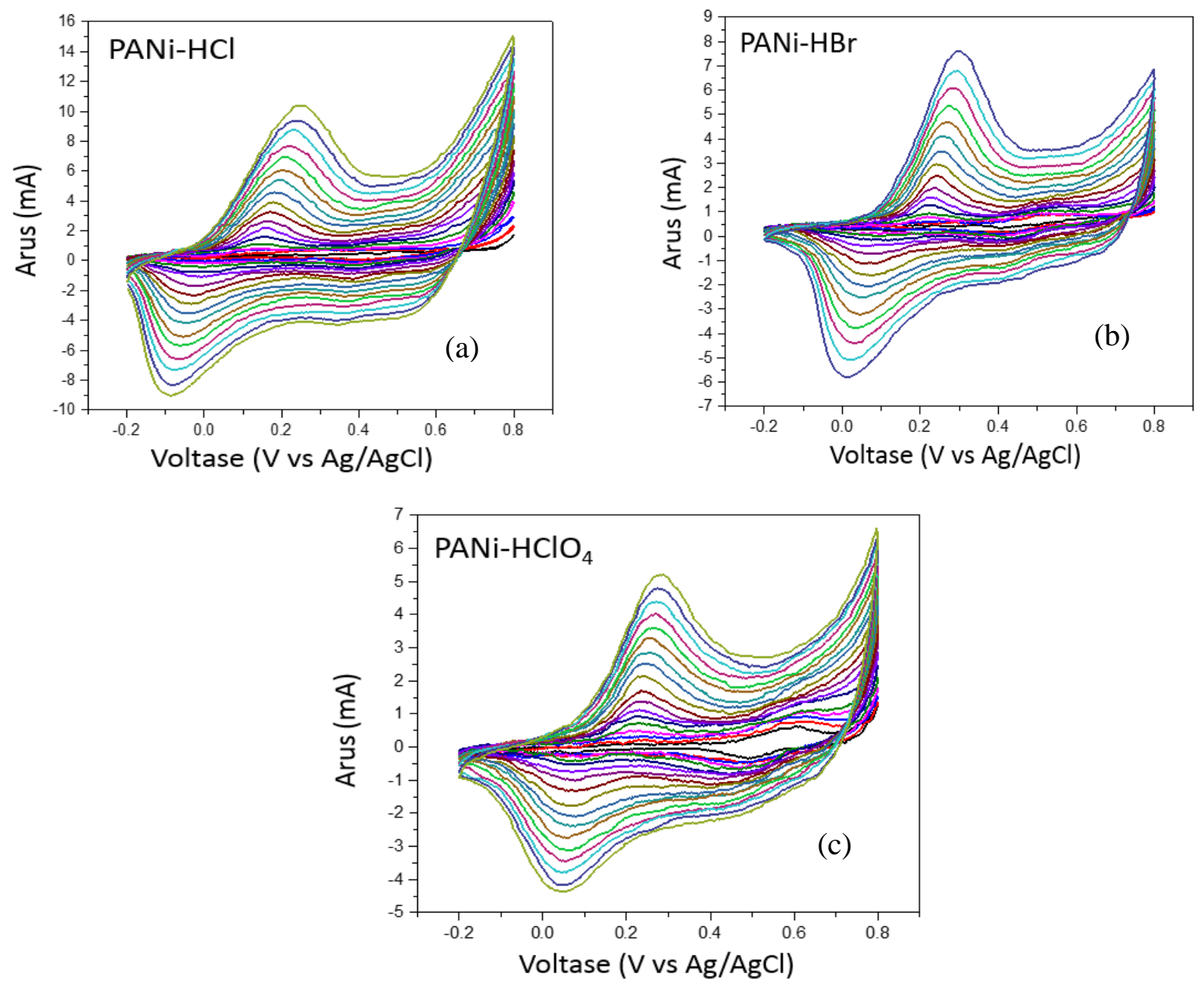

Gambar 4. Profil voltammogram dari proses elektrodeposisi anilina dengan asam dopan (a) $\mathrm{HCl}$, (b) $\mathrm{HBr}$, dan (c) $\mathrm{HClO}_{4}$. 
Intensitas puncak pada $1480 \mathrm{~cm}^{-1}$, terlihat sedikit lebih tinggi dibandingkan pada $1560 \mathrm{~cm}^{-1}$. Hal ini menunjukkan polianilina hasil sintesis memiliki jumlah cincin benzenoid yang lebih banyak dibandingkan cincin kuinoid. Intensitas pada $1480 \mathrm{~cm}^{-1}$ untuk leukoemeraldin, akan menunjukkan serapan yang kuat (Zhao $d k k$., 2018 ${ }^{\mathrm{b}}$ ).

Hal ini disebabkan leukoemeraldin tidak memiliki cincin benzenoid. Begitu juga dengan pernigranilin yang memiliki cincin kuinoid yang sama banyak dengan cincin benzenoid, akan menunjukkan intensitas puncak yang sama tinggi pada daerah $1560 \mathrm{~cm}^{-1}$ dan $1480 \mathrm{~cm}^{-1}$.

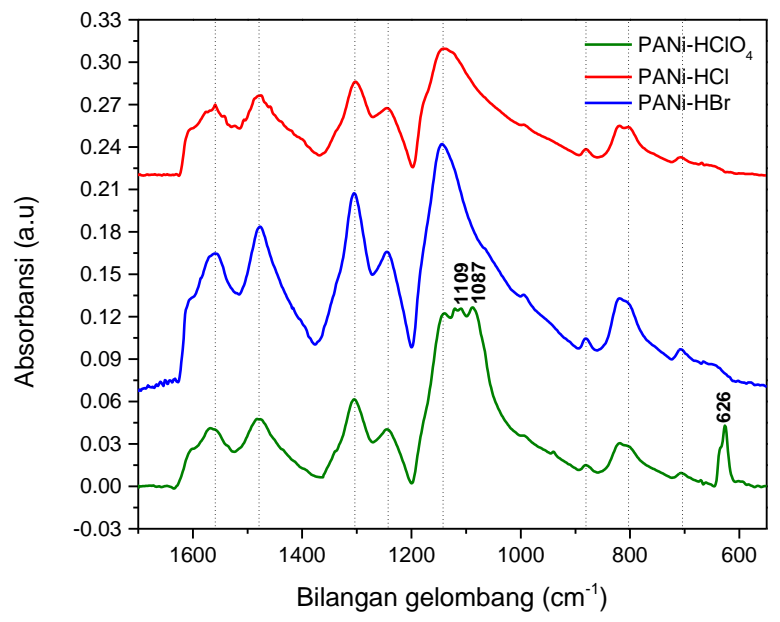

Gambar 5. Spektrum FT-IR dari polianilina hasil sintesis.

Selanjutnya, Serapan pada daerah $1302 \mathrm{~cm}^{-1}$ dan $1245 \mathrm{~cm}^{-1}$ merupakan Ulur $\mathrm{C}-\mathrm{N}$ dan Ulur $\left(\mathrm{C}-\mathrm{N}^{+} \bullet\right.$ ) pada kisi polaron. Pada daerah $1140 \mathrm{~cm}^{-1}$ merupakan puncak dari Regang $\mathrm{Q}=\mathrm{NH}^{+}-\mathrm{B}$ atau $\mathrm{Q}-\mathrm{NH}{ }^{+}-\mathrm{B}$ (Šeděnková $d k k$., 2016). Serapan tersebut khas terdapat pada emeraldin dan pernigranilin. Serapan pada daerah 820 $\mathrm{cm}^{-1}$ merupakan deformasi bidang luar $\mathrm{C}$ $\mathrm{H}$ (1,4-disubstitusi cincin) atau deformasi pada cincin kuinoid.
Karakter dari phenazine terlihat pada semua polianilina hasil sintesis pada serapan $870 \mathrm{~cm}^{-1}$ dalam intensitas yang cukup rendah. Phenazine merupakan salah satu produk minor dari sintesis polianilina (Šeděnková $d k k$., 2016). Intensitas puncak yang cukup tinggi pada $1302 \mathrm{~cm}^{-1}$, maka polianilina hasil sintesis merupakan garam emeraldin. Anion $\mathrm{ClO}_{4}^{-}$juga menunjukkan serapan di daerah $1109 \mathrm{~cm}^{-1}$ dan $1087 \mathrm{~cm}^{-1}$ (Taheri $d k k ., 2018$ ).

Tabel 1. Jenis mode vibrasi aktif Spektrum IR dari PAni

\begin{tabular}{|c|c|c|c|}
\hline \multirow{2}{*}{$\begin{array}{l}\text { Mode } \\
\text { Vibrasi }\end{array}$} & \multicolumn{3}{|c|}{$\begin{array}{c}\text { Bilangan } \\
\text { Gelombang }\left(\mathrm{cm}^{-1}\right)\end{array}$} \\
\hline & $\begin{array}{l}\text { PAni- } \\
\text { HCl }\end{array}$ & $\begin{array}{l}\text { PAni- } \\
\text { HBr }\end{array}$ & $\begin{array}{l}\text { PAni- } \\
\text { HClO }_{4}\end{array}$ \\
\hline $\begin{array}{c}\text { Ulur } \mathrm{C}=\mathrm{C} \\
\text { pada cincin } \\
\text { kuinoid }\end{array}$ & 1562 & 1560 & 1562 \\
\hline $\begin{array}{c}\text { Ulur } \mathrm{C}=\mathrm{C} \\
\text { pada cincin } \\
\text { benzenoid }\end{array}$ & 1479 & 1479 & 1482 \\
\hline Ulur $\mathrm{C}-\mathrm{N}$ & 1302 & 1301 & 1303 \\
\hline $\begin{array}{c}\text { Ulur }(\mathrm{C}- \\
\left.\mathrm{N}^{+\bullet}\right) \text { pada } \\
\text { kisi polaron }\end{array}$ & 1246 & 1245 & 1245 \\
\hline $\begin{array}{c}\text { Regang } \\
\mathrm{Q}=\mathrm{NH}^{+}-\mathrm{B} \\
\text { atau Q- } \\
\mathrm{NH}^{++}-\mathrm{B}\end{array}$ & 1142 & 1142 & 1141 \\
\hline Anion $\mathrm{ClO}_{4}^{-}$ & - & - & $\begin{array}{c}1109 \\
1087 \\
626 \\
\end{array}$ \\
\hline $\begin{array}{c}\text { Vibrasi } \\
\text { tekuk keluar } \\
\text { bidang pada } \\
\text { cincin } 1,2,4 \\
- \\
\text { trisubstitusi }\end{array}$ & 878 & 878 & 877 \\
\hline $\begin{array}{c}\text { Deformasi } \\
\text { bidang luar } \\
\text { (C-H) }(1,4- \\
\text { disubstitusi } \\
\text { cincin) } \\
\text { Deformasi } \\
\text { cincin } \\
\text { kuinoid }\end{array}$ & 819 & 818 & 819 \\
\hline
\end{tabular}




\section{Pengujian Kinerja Baterai}

Fabrikasi baterai dibuat dalam bentuk sandwich, PAni sebagai katoda sedangkan Zn sebagai anoda. Separator digunakan kertas saring yang berisikan elektrolit yang sesuai dengan pendopannya dan surfaktan Triton X-100. Triton X-100 digunakan untuk mencegah pembentukan Dendrit pada Zn (Zhao dkk., 2018 ${ }^{\mathrm{a}}$ ). Currefnt collector untuk PAni digunakan Graphite Sheet.

Pada pengujian performa baterai tersebut, proses pengisian dan pengosongan dilakukan selama 60 siklus menggunakan arus sebesar $10 \mathrm{~mA}$ untuk semua jenis baterai PAni. Batasan cut-off pengisian adalah 1,6 $\mathrm{V}$ dan pengosongan adalah $0,7 \mathrm{~V}$. Pemilihan batasan tersebut didasari pada perlakuan prekondisi pada baterai PAni. Pada prekondisi, cut-off pengisian digunakan $1,7 \mathrm{~V}$. Ternyata pada batasan tersebut, baterai tidak mampu melakukan pengisian lagi pada $1,64 \mathrm{~V}$. Hal ini disebabkan oleh keseluruhan PAni sudah teroksidasi.

Begitu juga halnya pada saat pengosongan, prekondisi dilakukan dengan cut-off pengosongan $0,1 \mathrm{~V}$. Hasil yang ditemukan, pada $0,7 \mathrm{~V}$ terjadi penurunan yang drastis menuju $0 \mathrm{~V}$ yang sesuai dengan cut-off pengosongan. Hal yang serupa dengan proses pengisian, hal ini mengindikasikan bahwa keseluruhan PAni sudah tereduksi. Proses pengisian dan pengosongan diilustrasikan pada Gambar 6.

Ketika dilakukan pengosongan, maka Zn akan mengalami oksidasi dengan melepas kation $\mathrm{Zn}^{2+}$, lalu PAni emeraldin akan tereduksi menjadi leukoemeraldin dengan melepas dopannya. Seluruh ion yang dihasilkan akan menuju ke fasa bulk. Setelah itu, pada proses pengisian, Zn akan mengalami reduksi sedangkan PAni leukoemeraldin akan mengalami oksidasi kembali menjadi emeraldin dengan pengikatan dopan.

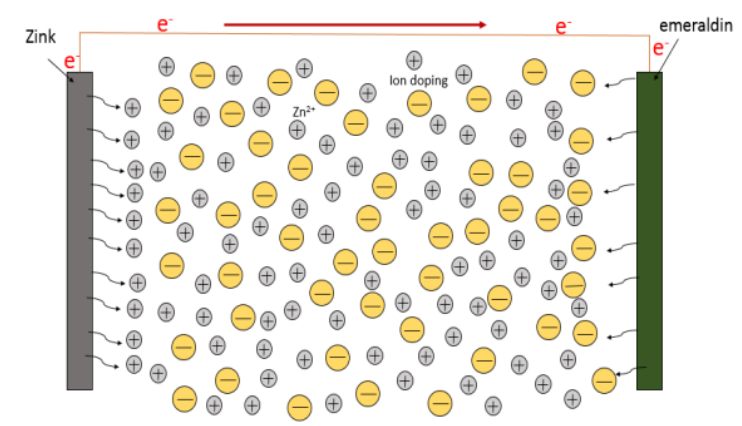

(a)

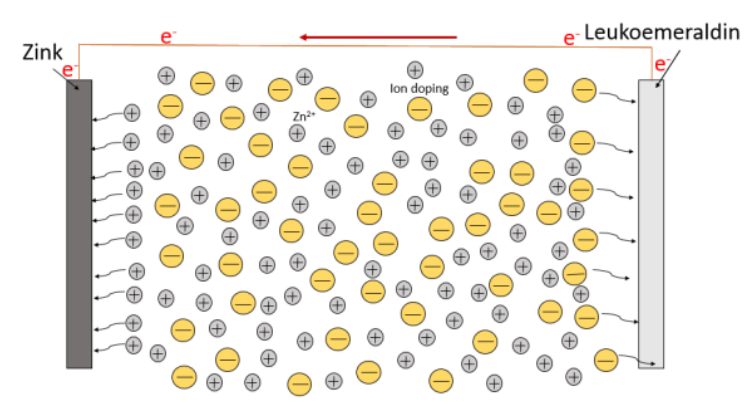

(b)

Gambar 6. Reaksi yang terjadi dan Ilustrasi baterai PAni pada saat (a) pengosongan dan (b) pengisian.

Baterai PAni dengan dopan $\mathrm{Cl}$ dan $\mathrm{Br}$ menunjukkan hasil yang cukup stabil pada 60 siklus pengisian-pengosongan seperti ditunjukkan pada Gambar 7. Kapasitas baterai PAni-Cl dan PAni-Br pada awal siklus adalah 59,49 dan 49,30 $\mathrm{mAh} \mathrm{g}^{-1}$. Lose capacity baterai PAni-Cl dan PAni-Br sampai pada siklus terakhir adalah $6,77 \%$ dan $24,14 \%$. Baterai PAni$\mathrm{ClO}_{4}$ memiliki kapasitas awal cukup tinggi yaitu $68,23 \mathrm{mAh} \mathrm{g}^{-1}$, tetapi pada siklus ke 60 kapasitas menurun drastis menjadi 10,2 mAh $\mathrm{g}^{-1}$ dengan Lose capacity baterai $\mathrm{PAni}_{-} \mathrm{ClO}_{4}$ sebesar $85,05 \%$. 


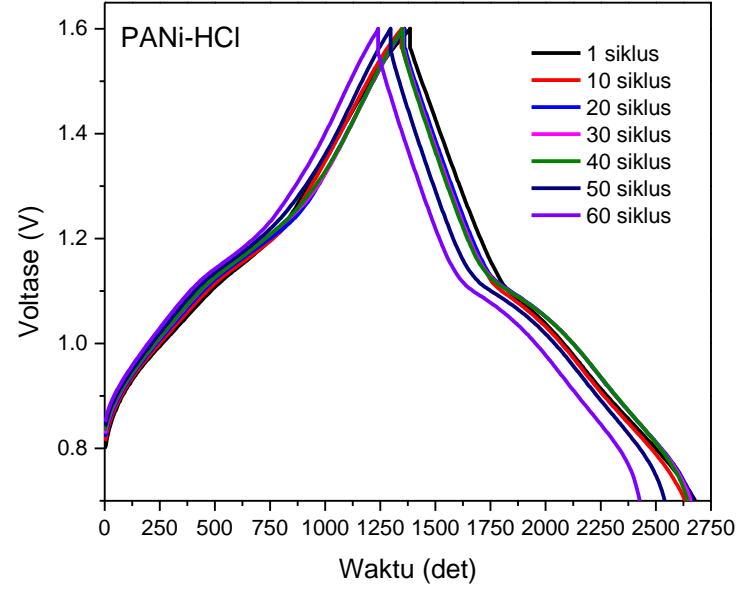

(a)

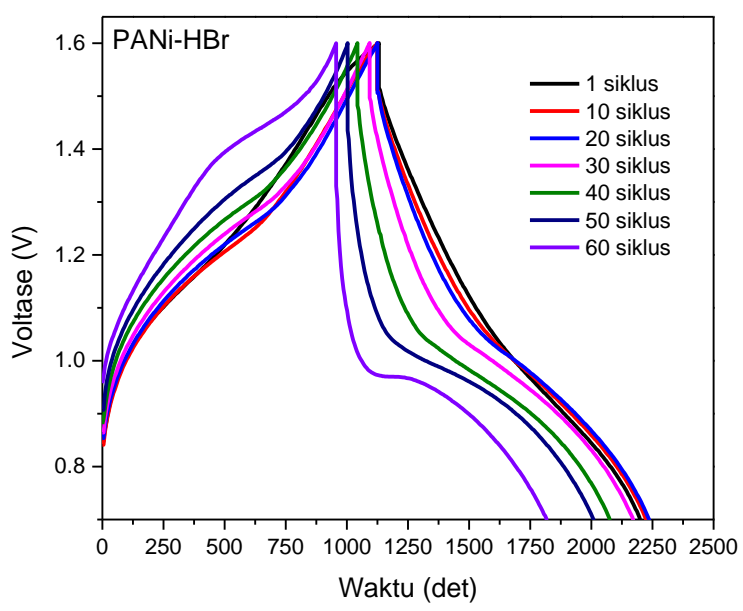

(b)

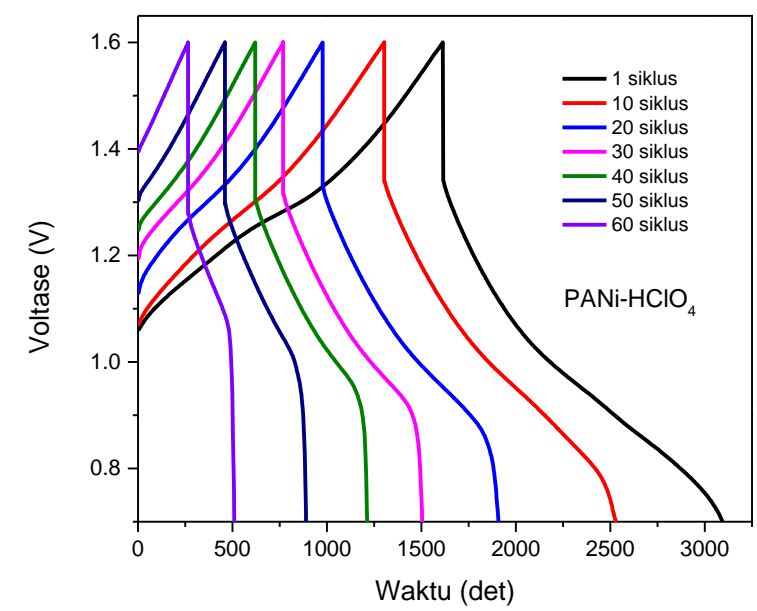

(c)

Gambar 7. Proses pengisian-pengosongan dari baterai PAni dengan dopan (a) $\mathrm{HCl}$, (b) $\mathrm{HBr}$, (c) $\mathrm{HClO}_{4}$.

Kapasitas energi pada siklus pertama dari baterai PAni-Cl adalah 68,41 $\mathrm{mWh} \mathrm{g}^{-}$ ${ }^{1}$, sedangkan PAni-Br adalah 56,69 $\mathrm{mWh}$ $\mathrm{g}^{-1}$. Dari data tersebut dapat disimpulkan bahwa baterai PAni-Cl dan PAni-Br menunjukkan performa yang baik. Namun, baterai PAni-Br memiliki kapasitas baterai yang lebih rendah jika dibandingkan dengan baterai PAni-Cl.

Fenomena tersebut dikaji lebih lanjut menggunakan impedansi. Pengukuran dilakukan pada frekuensi $0,1 \mathrm{~Hz}$ sampai $100 \mathrm{kHz}$. Plot Nyquist yang dihasilkan ditampilkan pada Gambar 8. Hasil fitting kurva cocok dengan model sirkuit pada
Gambar 8.b. Pada model tersebut, tergambarkan bahwa sistem baterai PAni memiliki beberapa karakter hambatan yaitu Resistansi larutan $\left(\mathrm{R}_{\mathrm{s}}\right)$ dan Resistansi charge transfer $\left(\mathrm{R}_{\mathrm{ct}}\right)$ yang dapat dilihat pada Tabel 2. Begitu juga dengan elemen CPE (Constant Phase element) yang memungkinkan terbentuknya kapasitor yang tidak ideal. Pembentukan CPE ini sebagai simbol dari interaksi permukaan elektroda dengan elektrolit. Dalam hal ini keberadaan CPE akan mempengaruhi $\mathrm{R}_{\mathrm{s}}$ dan $R_{c t}$. 
Hasil fitting menunjukkan nilai $\mathrm{R}_{\mathrm{s}}$ dari baterai PAni-Cl lebih kecil dari PAni$\mathrm{HBr}$ dan $\mathrm{PAni}-\mathrm{ClO}_{4}$. Kecenderungan yang sama juga ditunjukkan pada baterai PAni$\mathrm{Cl}$ yang memiliki nilai $\mathrm{R}_{\mathrm{ct}}$ lebih kecil dibandingkan $\mathrm{PAni}-\mathrm{Br}$ dan $\mathrm{PAni}-\mathrm{ClO}_{4}$. Kesimpulan dari hasil impedansi tersebut adalah baterai PAni-Cl memiliki total resistasi yang lebih kecil dibandingkan dengan baterai PAni-Br dan $\mathrm{PAni}_{-} \mathrm{ClO}_{4}$. Hal ini cocok dengan performa dari setiap baterai. Baterai PAni-Cl yang memiliki performa terbaik memiliki resistansi total yang kecil.

Tabel 2. Parameter elektrik dari Impedansi

\begin{tabular}{|c|c|c|}
\hline \multirow{2}{*}{ Sampel } & \multicolumn{2}{|c|}{ Electrical parameter } \\
\hline & $\mathbf{R}_{\mathrm{s}}(\Omega)$ & $\mathbf{R}_{\mathrm{ct}}(\Omega)$ \\
\hline PAni-HCl & 1.38 & 2.24 \\
\hline PAni-HBr & 2.56 & 2.97 \\
\hline $\mathrm{PAni}^{-\mathrm{HClO}_{4}}$ & 3.03 & 7.71 \\
\hline
\end{tabular}

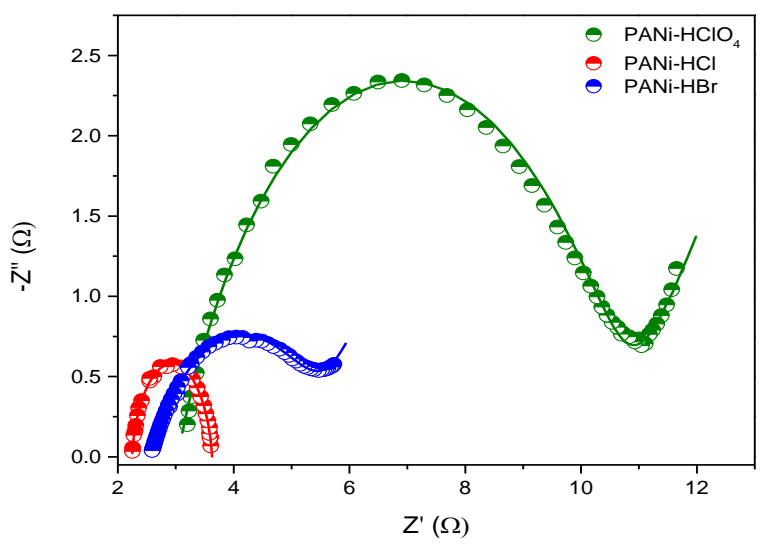

(a)

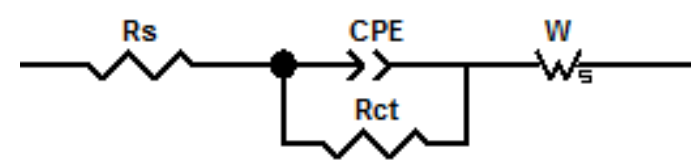

(b)

Gambar 8. (a) Ploting Nyquist dari setiap baterai PAni (b) Model sirkuit yang ekivalen dengan kurva tersebut.
Untuk menjelaskan nilai dari $\mathrm{R}_{\mathrm{s}}$ dan $\mathrm{R}_{\mathrm{ct}}$ tersebut, dicoba dengan pendekatan proses mobilisasi anion dopan menuju elektroda pada saat proses pengisianpengosongan berlangsung. Proses pengisian terjadi oksidasi leukoemeraldin yang melibatkan pengikatan kembali anion dopan pada permukaan PAni.

Pada saat mobilisasi terjadi, anion harus melewati beberapa lapisan di dekat elektroda seperti diilustrasikan pada Gambar 9. Anion dalam keadaan tersolvasi akan mengalami desolvasi pada lapisan OHP (Zhao dkk., 2018 ${ }^{\mathrm{a}}$ ). Jari-jari dari ion $\mathrm{Cl}^{-}$lebih kecil dibanding dengan $\mathrm{Br}^{-}$, begitu juga $\mathrm{Br}^{-}$lebih kecil dibandingkan dengan $\mathrm{ClO}_{4}^{-}$yaitu berturutturut $0,181,0,196$, dan $0,250 \mathrm{~nm}$, sehingga pergerakan anion $\mathrm{Cl}^{-}$pada OHP akan lebih cepat dibandingkan anion lain. Hal ini menyebabkan nilai $\mathrm{R}_{\mathrm{s}} \mathrm{PAni-Cl}$ lebih rendah dibandingkan dengan anion lain.

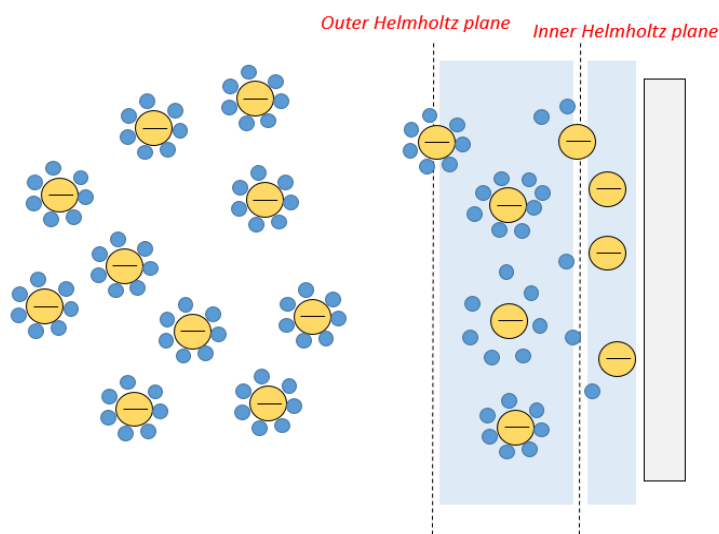

Gambar 9. Ilustrasi ion termobilisasi menuju elektroda.

Pada saat anion mengalami desolvasi pada OHP, selanjutnya anion tersebut akan kembali termobilisasi menuju IHP. Pada IHP adalah area kontak langsung anion dengan elektroda, yang seluruh anion tidak lagi mengikat air. 
Kecenderungan jari-jari ion $\mathrm{Cl}^{-}<\mathrm{Br}^{-}<$ $\mathrm{ClO}_{4}^{-}$, oleh karena itu pergerakan ion $\mathrm{Cl}^{-}$ pada IHP juga akan lebih cepat dibandingkan anion lain. Hal ini yang mempengaruhi proses charge transfer.

Pengujian baterai PAni|Zn dilakukan dengan menghidupkan lampu LED yang bewarna merah. Hasil pengujian baterai bertahan selama \pm 4 menit. Hasil dari pengujian disajikan pada Gambar 10 . Penelitian ini perlu dilakukan pengembangan kedepannya dalam hal pengemasan baterai. Pada Gambar 10 cukup terlihat bahwa pembuatan baterai masih memiliki rongga disetiap sisi sistem, sehingga faktor elektrolit menguap dan udara masuk juga akan mempengaruhi performa keseluruhan dari baterai PAni|Zn.

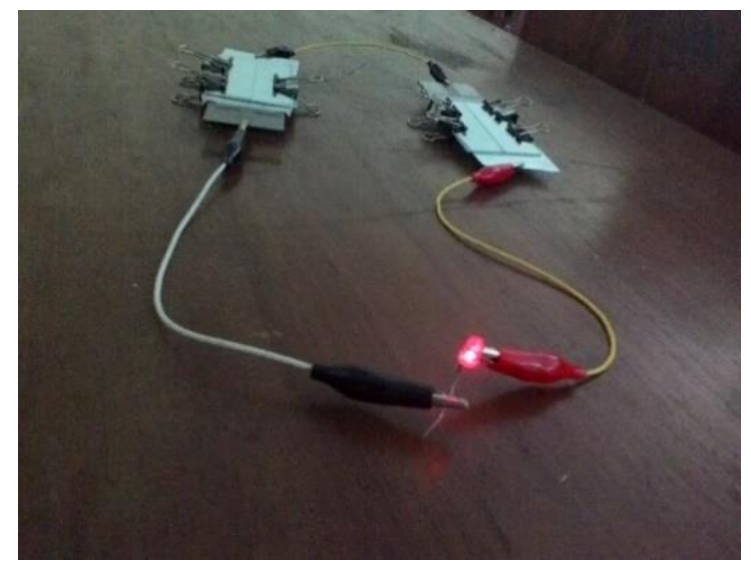

Gambar 10. Uji coba pada LED dengan baterai ukuran $6 \times 4 \mathrm{~cm}$.

\section{KESIMPULAN}

Baterai PAni|Zn dengan asam pendopan $\mathrm{HCl}$ dan $\mathrm{HBr}$ emiliki stabilitas pengisian dan pengosongan terbaik dibandingkan dengan asam dopan $\mathrm{HClO}_{4}$. Hal ini ditunjukkan dengan nilai persen lose capacity sampai siklus terakhir masing-masing $6,77 \%$; 24,14\%; dan 85,05\%. Resistansi total baterai PAni|Zn dengan asam pendopan $\mathrm{HCl}$ lebih rendah di bandingkan dengan baterai PAni|Zn dengan asam pendopan yang lain.

Besarnya jari-jari hidrasi ion menyebabkan mobilisasi ke OHP menjadi lambat, sehingga menimbulkan $R_{s}$ yang cukup besar. Begitu juga dengan besarnya jari-jari hidrasi ion menyebabkan mobilisasi ke IHP setelah desolvasi menjadi lambat, sehingga proses charge transfer menjadi semakin sulit. Hal ini menyebabkan meningkatnya nilai $R_{c t}$. Baterai PAni-Zn memiliki standar nilai $\mathrm{V}_{\mathrm{oc}}$ dan power density yang mirip dengan baterai Ni-MH, sehingga dapat menjadi baterai sekunder alternatif masa depan.

\section{DAFTAR RUJUKAN}

Chang, X., Hu, R., Sun, S., Liu, J., Lei, Y., Liu, T., Dong, L., \& Yin, Y. (2018). Sunlight-charged electrochromic battery based on hybrid film of tungsten oxide and polyaniline. Applied Surface Science, 441, 105112.

https://doi.org/10.1016/j.apsusc. 2018 .02 .003

Chen, Y., \& Manzhos, S. (2016). Voltage and capacity control of polyaniline based organic cathodes: An ab initio study. Journal of Power Sources, 336, 126-131. https://doi.org/10.1016/j.jpowsour.20 16.10 .066

Deyab, M. A., \& Mele, G. (2019). Polyaniline/Zn-phthalocyanines nanocomposite for protecting zinc electrode in Zn-air battery. Journal of Power Sources, 443, 227264. https://doi.org/10.1016/j.jpowsour.20 19.227264

Gao, H., Lu, Q., Yao, Y., Wang, X., \& Wang, F. (2017). Significantly Raising the Cell Performance of Lithium Sulfur Battery via the Multifunctional Polyaniline Binder. Electrochimica Acta, 232, 414-421. 
https://doi.org/10.1016/j.electacta.20 17.02 .160

Hatchett, D. W., Josowicz, M., \& Janata, J. (1999). Acid doping of poly aniline: Spectroscopic and electrochemical studies. Journal of Physical Chemistry B, 103(50), 10992-10998. https://doi.org/10.1021/jp991110z

Huang, J., Tu, J., Lv, Y., Liu, Y., Huang, H., Li, L., \& Yao, J. (2020). Achieving mesoporous $\mathrm{MnO} 2 @$ polyaniline nanohybrids via a gas/liquid interfacial reaction between aniline and $\mathrm{KMnO} 4$ aqueous solution towards $\mathrm{Zn}-\mathrm{MnO} 2$ battery. Synthetic Metals, 266, 116438.

https://doi.org/10.1016/j.synthmet.20 20.116438

Kawashima, H., Okatani, R., Mayama, H., Nakamura, Y., \& Fujii, S. (2018). Synthesis of hydrophobic polyanilines as a light-responsive liquid marble stabilizer. Polymer, 148 , 217-227. https://doi.org/10.1016/j.polymer.201 8.06.039

Kurada, K. V., \& De, S. (2018). Polyaniline doped ultrafiltration membranes: Mechanism of membrane formation and $\mathrm{pH}$ response characteristics. Polymer, 153, 201-213. https://doi.org/10.1016/j.polymer.201 $\underline{8.08 .032}$

Li, X., Lv, R., Zou, S., Na, B., Liu, P., Ma, Y., \& Liu, H. (2019). Polyaniline nanopillars on surface cracked carbon fibers as an ultrahighperformance cathode for a flexible rechargeable aqueous Zn-ion battery. Composites Science and Technology, 180, 71-77. https://doi.org/10.1016/j.compscitech .2019 .05 .016

Luo, J., Zhong, W., Zou, Y., Xiong, C., \& Yang, W. (2016). Preparation of morphology-controllable polyaniline and polyaniline/graphene hydrogels for high performance binder-free supercapacitor electrodes. Journal of Power Sources, 319, 73-81. https://doi.org/10.1016/j.jpowsour.20 16.04.004

Šeděnková, I., Trchová, M., Dybal, J., \& Stejskal, J. (2016). Interaction of polyaniline film with dibutyl phosphonate versus phosphite: Enhanced thermal stability. Polymer Degradation and Stability, 134, 357365.

https://doi.org/10.1016/j.polymdegra dstab.2016.11.005

Sovizi, M. R., \& Fahimi, Z. (2018). Honeycomb polyaniline-dodecyl benzene sulfonic acid (hPANIDBSA)/sulfur as a new cathode for high performance $\mathrm{Li}-\mathrm{S}$ batteries. Journal of the Taiwan Institute of Chemical Engineers, 86, 270-280. https://doi.org/10.1016/j.jtice.2018.0 3.004

Taheri, N. N., Ramezanzadeh, B., Mahdavian, M., \& Bahlakeh, G. (2018). In-situ synthesis of Zn doped polyaniline on graphene oxide for inhibition of mild steel corrosion in 3.5 wt.\% chloride solution. Journal of Industrial and Engineering Chemistry, 63, 322-339. https://doi.org/10.1016/j.jiec.2018.02 .033

Zhang, X., Lin, Q., Zhang, X., \& Peng, K. (2018). A novel 3D conductive network-based polyaniline/graphitic mesoporous carbon composite electrode with excellent electrochemical performance. Journal of Power Sources, 401, 278286.

https://doi.org/10.1016/j.jpowsour.20 18.08 .091

ahao, C., Jin, Y., Du, X., \& Du, W. (2018). In situ prepared amorphous FeCoO-Polyaniline/multiwalled carbon nanotube nanohybrids as efficient oxygen evolution catalysts for rechargeable $\mathrm{Zn}$-air batteries. 
Journal of Power Sources, 399, $337-$ 342.

https://doi.org/10.1016/j.jpowsour.20 18.07.111

bZhao, Z., Yu, T., Miao, Y., \& Zhao, X. (2018). Chloride ion-doped polyaniline/carbon nanotube nanocomposite materials as new cathodes for chloride ion battery. Electrochimica Acta, 270, 30-36. https://doi.org/10.1016/j.electacta.20 $\underline{18.03 .077}$ 